Volume 16 (2) (2020) : 137-158
Jurnal Borne0 Administrator
p-issn : 1858-0300; e-issn : 2407-6767
http://samarinda.lan.go.id/jba
DOI : 10.24258/jba.v16i2.654

\title{
UPAYA PENINGKATAN KAPABILITAS APARAT PENGAWASAN INTERN PEMERINTAH (APIP) DI ACEH MELALUI INTERNAL AUDIT CAPABILITY MODEL (IACM)
}

\section{IMPROVEMENT EFFORTS OF INTERNAL GOVERNMENT SUPERVISORY APPARATUS (APIP) IN ACEH THROUGH INTERNAL AUDIT CAPABILITY MODEL (IACM)}

\author{
Rati Sumanti \\ Pusat Pelatihan dan Pengembangan dan Kajian Hukum Administrasi Negara \\ Lembaga Administrasi Negara (Puslatbang KHAN LAN) \\ Jl. Dr. Mr. Muhammad Hasan, Lamcot, Aceh Besar, Aceh \\ Email: ratisumanti@gmail.com
}

Naskah diterima: 24 Februari 2020; revisi terakhir: 26 Juni 2020; disetujui 25 Juli 2020

How to Cite: Sumanti, Rati. (2020). Upaya Peningkatan Kapabilitas Aparat Pengawasan Intern Pemerintah (APIP) di Aceh melalui Internal Audit Capability Model (IACM). Jurnal Borneo Administrator, 16 (2), 137-158. https://doi.org/10.24258/jba.v16i2.654

\begin{abstract}
Internal Government Supervisory Apparatus (APIP) is an actor who conducts internal audit. The top level of capability of APIP shows that APIP is getting better in carrying out its role as an internal supervisor. However, not all APIP in Aceh have a good level of capability. Therefore, the Aceh BPKP Representative as the APIP supervisor agency seeks to increase the level of APIP capabilities through the Internal Audit Capability Model (IACM). This study aims to describe how the implementation of IACM in the region is proven to increase the capability level of APIP. Using a qualitative approach with a case study method, interviews were conducted with officials in the Aceh BPKP who were considered being representative so they could provide accurate information on the problem under study. There are 6 elements capability of APIP comprising 24 key process areas to reach level 3. Representatives of BPKP Aceh have improved capabilities of the six elements capability of APIP. Coaching conducted comprehensively has fulfilled 24 key process areas required in IACM including coaching and consulting activities. The findings in this study showed that of the 24 APIP in Aceh, 16 APIP or 67\% have increased capability levels. This means that implementing IACM conducted by the Aceh BPKP Representative shows a positive impact on improving the capabilities of APIP. So this research contributes to the practice where other local governments can adopt the efforts and improvements that need to be made according to the six elements of APIP capabilities.
\end{abstract}

Keywords: Internal Audit, Internal Government Supervisory Apparatus (APIP), Capabilityof APIP, Finance and Development Supervisory Agency (BPKP) 


\begin{abstract}
Abstrak
Aparat Pengawasan Intern Pemerintah (APIP) adalah aktor yang melakukan pengawasan intern. Tingginya level kapabilitas APIP menunjukkan semakin baik pula APIP dalam menjalankan perannya sebagai pengawas intern. Namun demikian, belum semua APIP di Aceh memiliki level kapabilitas yang baik. Oleh karenanya, Perwakilan BPKP Aceh selaku instansi pembina APIP berupaya melakukan peningkatan level kapabilitas APIP melalui Internal Audit Capability Model (IACM). Penelitian ini bertujuan untuk melihat gambaran bagaimana penerapan IACM di daerah apakah terbukti mampu meningkatkan level kapabilitas APIP. Menggunakan pendekatan kualitatif dengan metode studi kasus, dilakukan wawancara kepada Pejabat di Perwakilan BPKP Aceh yang dianggap representatif sehingga dapat memberikan informasi yang akurat terhadap masalah yang diteliti. Ada 6 elemen kapabilitas APIP yang terdiri atas 24 area proses kunci untuk mencapai level 3. Perwakilan BPKP Aceh telah meningkatkan kapabilitas pada enam elemen kapabilitas APIP tersebut. Pembinaan yang dilakukan secara komprehensif telah memenuhi 24 area proses kunci yang dipersyaratkan dalam IACM, yang meliputi kegiatan pembinaan dan konsultasi. Temuan dalam penelitian ini menunjukkan bahwa dari 24 APIP di wilayah Aceh, 16 APIP Pemerintah Daerah atau 67\% mengalami peningkatan level kapabilitas. Hal ini berarti penerapan IACM yang dilakukan oleh Perwakilan BPKP Aceh menunjukkan dampak positif bagi peningkatan kapabilitas APIP, sehingga penelitian ini memberikan kontribusi praktik sehingga pemerintah daerah lainnya dapat mengadopsi upaya-upaya serta perbaikan yang perlu dilakukan sesuai enam elemen kapabilitas APIP.
\end{abstract}

Kata kunci: Pengawasan Internal, Aparat Pengawasan Intern Pemerintah (APIP), Kapabilitas APIP, Badan Pengawasan Keuangan dan Pembangunan (BPKP)

\title{
A. PENDAHULUAN
}

Agar penyelenggaraan pemerintahan dapat berjalan efektif dan efisien, diperlukan pengawasan internal mulai dari tahap perencanaan sampai pada tahap pertanggungjawaban dan pelaporan. Pengawasan intern yang efektif berpengaruh dan menunjukan arah yang positif terhadap penerapan good governance sehingga dapat meningkatkan kinerja pemerintah daerah (Darmawiguna, 2017:2191). Penelitian lain yang dilakukan oleh Widanarto (2012:12) juga menemukan bahwa besarnya pengaruh langsung dari pengawasan internal terhadap kinerja Pemerintah Kota Bandung adalah sebesar 23 persen. Hal ini berarti pengawasan internal yang dilakukan oleh Inspektorat Kota Bandung cukup efektif dalam pencapaian kinerja Pemerintah Kota Bandung.

Pengawasan intern dilakukan oleh aparat pengawasan intern pemerintah (APIP) sehingga APIP dituntut untuk dapat menyimpulkan kesalahan yang terjadi di instansi pemerintah masuk ke ranah pidana (korupsi) atau hanya kesalahan administratif saja (Puslatbang KHAN, 2019:58). Hal tersebut menjadi tantangan bagi APIP untuk meningkatkan kompetensinya karena kompetensi berpengaruh terhadap efektivitas audit yang pada akhirnya menambah keefektifan kinerja organisasi-organisasi yang ada pada pemerintahan daerah (Primasatya, D dkk, 2019:7). Dari aspek kode etik dan standar audit, penugasan audit intern menekankan kompetensi dan kecermatan profesional. Karena itu, audit idealnya dilakukan oleh para auditor yang kompeten dan cermat (Gunanjar, G dkk, 2019:27).

Kompetensi APIP dapat dilihat dari level kapabilitas APIP itu sendiri. Semakin tinggi level kapabilitas APIP menunjukkan semakin baik pula kinerja APIP dalam menjalankan perannya sebagai auditor. Berdasarkan Laporan Kinerja BPKP 2018, dari 34 Pemerintah 
Provinsi, baru 20 APIP yang mencapai tingkat kapabilitas APIP level 3 dan 3 Dengan Catatan (DC). Dengan demikian, masih ada 14 Pemerintah Provinsi yang masih memiliki kapabilitas APIP di bawah level 3 (BPKP, 2018:90).

Tabel 1.

Perkembangan Jumlah APIP Pemerintah Provinsi Kapabilitas Level 3

\begin{tabular}{|c|c|c|c|c|c|}
\hline \multirow[t]{2}{*}{ No } & \multirow{2}{*}{$\begin{array}{l}\text { Populasi } \\
\text { APIP } \\
\text { Pemprov }\end{array}$} & \multicolumn{3}{|c|}{$\begin{array}{l}\text { Jumlah APIP Pemerintah } \\
\text { Provinsi Kapabilitas Level } 3\end{array}$} & \multirow{2}{*}{$\begin{array}{l}\text { APIP Pemerintah Provinsi Kapabilitas } \\
\text { dengan Level } 3\end{array}$} \\
\hline & & 2017 & 2018 & Kenaikan & \\
\hline 1 & 34 & 18 & 20 & 2 & $\begin{array}{l}\text { Level 3: } \\
\text { 1. DI Yogyakarta }\end{array}$ \\
\hline
\end{tabular}

Level 3 DC:

2. Sumatera Barat, 3. Kepulauan Riau, 4. Lampung, 5. DKI Jakarta, 6. Jawa Barat, 7. Jawa Tengah, 8. Jawa Timur, 9. Kalimantan Barat, 10. Kalimantan Timur, 11. Kalimantan Tengah, 12. Kalimantan Selatan, 13. Kalimantan Utara, 14. Gorontalo, 15. Sulawesi Barat, 16. Bali, 17. Nusa Tenggara Barat, 18. Nusa Tenggara Timur, 19. Maluku. 20. Maluku Utara

Sumber: Laporan Kinerja BPKP, 2018:90

Di sisi lain, APIP sebagai third line of defence yang mampu memberi keyakinan terkait efisiensi, efektivitas dan kepatuhan serta sebagai trusted advisor merupakan pihak yang dicari-cari oleh pelaku korupsi untuk menutupi perbuatannya, terutama apabila APIP tersebut mampu menemukan perbuatan korupsi tersebut (Rustendi, 2017:113). Pengawasan intern yang belum efektif menjadi salah satu penyebab masih maraknya korupsi, kolusi dan nepotisme, akibatnya akuntabilitas kinerja rendah serta masih buruknya kualitas pelayanan publik. Sesuai dengan apa yang disampaikan oleh BPKP (2018:2) dalam Konferensi dan Musyawarah Nasional Auditor Intern Pemerintah Indonesia Tahun 2018 bahwa APIP ikut bertanggung jawab atas munculnya perilaku korupsi yang disebabkan rendahnya kompetensi dan integritas individu (mikro-individual), lemahnya pengendalian intern, tata kelola dan manajemen risiko korupsi (meso-organisasional) serta belum optimalnya sinergi dan kolaborasi antarinstitusi pengelola risiko korupsi di Indonesia (makro-nasional).

Akibat besarnya tuntutan terhadap peningkatan kapabilitas APIP, maka BPKP yang juga merupakan APIP berkewajiban untuk melakukan pembinaan kapabilitas APIP. Tertuang dalam Peraturan Presiden Republik Indonesia Nomor 192 Tahun 2014 tentang Badan Pengawasan Keuangan dan Pembangunan, Pasal 3 disebutkan bahwa dalam melaksanakan tugasnya, BPKP menyelenggarakan 14 fungsi, salah satunya pada huruf $\mathrm{j}$, yaitu pembinaan kapabilitas pengawasan intern pemerintah dan sertifikasi jabatan fungsional auditor.

Untuk menjalankan fungsi di atas, Perwakilan BPKP Aceh telah menetapkan 4 misi, salah satunya pada misi keempat berbunyi "mengembangkan kapasitas pengawasan intern pemerintah yang profesional dan kompeten”. Pada Laporan Kinerja Perwakilan BPKP Aceh 
2019, dari 23 APIP di Aceh, terdapat delapan APIP Pemerintah Kabupaten/Kota yang mencapai tingkat kapabilitas APIP level 3 (Perwakilan BPKP Aceh, 2019:69).

Tabel 2.

Kapabilitas APIP Pemda Tahun 2018

Perwakilan BPKP Aceh

\begin{tabular}{|c|c|c|c|c|c|}
\hline No & Nama Pemda & & & Level & \\
\hline 1 & PROVINSI ACEH & & & 2 & \\
\hline No & Nama Pemda & Level & No & Nama Pemda & Level \\
\hline & KABUPATEN/KOTA & & & KABUPATEN/KOTA & \\
\hline 1 & Inspektorat Kab. Aceh Barat & $2+$ & 13 & Inspektorat Kab. Aceh Besar & 2 \\
\hline 2 & $\begin{array}{l}\text { Inspektorat Kab. Aceh } \\
\text { Selatan }\end{array}$ & $2+$ & 14 & $\begin{array}{l}\text { Inspektorat Kota } \\
\text { Lhokseumawe }\end{array}$ & 2 \\
\hline 3 & Inspektorat Kota Banda Aceh & $2+$ & 15 & Inspektorat Kab. Pidie & 2 \\
\hline 4 & Inspektorat Kota Langsa & $2+$ & 16 & Inspektorat Kab. Pidie Jaya & 2 \\
\hline 5 & Inspektorat Kab. Aceh Timur & $2+$ & 17 & Inspektorat Kab. Nagan Raya & 2 \\
\hline 6 & $\begin{array}{l}\text { Inspektorat Kab. Bener } \\
\text { Meriah }\end{array}$ & $2+$ & 18 & $\begin{array}{l}\text { Inspektorat Kab. Aceh Barat } \\
\text { Daya }\end{array}$ & 2 \\
\hline 7 & $\begin{array}{l}\text { Inspektorat Kab. Aceh } \\
\text { Tengah }\end{array}$ & $2+$ & 19 & $\begin{array}{l}\text { Inspektorat Kab. Aceh } \\
\text { Tenggara }\end{array}$ & 2 \\
\hline 8 & Inspektorat Kab. Aceh Utara & $2+$ & 20 & Inspektorat Kab. Simeulue & 2 \\
\hline 9 & $\begin{array}{l}\text { Inspektorat Kab. Aceh } \\
\text { Tamiang }\end{array}$ & 2 & 21 & Inspektorat Kab. Bireuen & $1+$ \\
\hline 10 & Inspektorat Kab. Gayo Lues & 2 & 22 & Inspektorat Kota Sabang & $1+$ \\
\hline 11 & $\begin{array}{l}\text { Inspektorat Kab. Aceh } \\
\text { Singkil }\end{array}$ & 2 & 23 & Inspektorat Kab. Aceh Jaya & 1 \\
\hline 12 & $\begin{array}{l}\text { Inspektorat Kota } \\
\text { Subulussalam }\end{array}$ & 2 & & & \\
\hline
\end{tabular}

Sumber: Laporan Kinerja Perwakilan BPKP Aceh Tahun 2019

Dari data di atas dapat diketahui bahwa kapabilitas APIP Pemerintah Provinsi Aceh berada pada level 2. Sedangkan untuk APIP di Kabupaten/Kota hanya 8 APIP di posisi level 2+, 12 APIP berada di level 2, bahkan masih ada APIP di level 1 dan 1+. Itu artinya belum ada APIP di Aceh yang mampu menjamin proses tata kelola yang sesuai dengan peraturan sehingga belum dapat secara maksimal mengurangi praktik korupsi.

Salah satu model yang dapat diimplementasikan untuk menaikkan level kapabilitas APIP adalah Internal Audit Capabilty Model (IACM). Hasil penelitian Maryani (2017:101), menemukan bahwa institusionalisasi IACM di Kementerian Luar Negeri berimplikasi terhadap APIP yang semakin berkompeten dan memahami kondisi yang masih perlu diperbaiki dengan pengembangan, baik individu, tim dan organisasi. Namun, fokus penelitian tersebut terletak pada institusionalisasi IACM dan dianalisis dengan teori institusional guna melihat fenomena yang terjadi, sehingga penelitiannya diharapkan dapat berkontribusi teoritis bahwa teori institusional relevan digunakan untuk menganalisis dan mempelajari pengadopsian suatu sistem yang dapat mendorong perubahan organisasi.

Berbeda dengan Bandi (2015:152) dalam penelitiannya mengungkapkan bahwa kapabilitas APIP yang diukur dalam IACM, secara penilaian individu tidak berpengaruh signifikan terhadap opini audit BPK RI atas laporan keuangan pemerintah daerah. Dalam 
penjelasan lanjutannya disebutkan bahwa berdasarkan fakta dan data di lapangan, level kapabilitas (APIP) inspektorat daerah rata-rata masih berada di level 1 dan 2 sehingga masih menjadi kendala untuk dapat memeriksa seluruh pos keuangan secara cermat dan mendetail, sehingga kinerja audit intern menjadi kurang optimal. Penelitian yang dilakukan oleh Bandi tersebut, tidak menganalisis kapabilitas APIP dari enam elemen secara lengkap, tetapi hanya melihat kapabilitas APIP dari keterbatasan jumlah aparat (APIP), tingkat kompetensi, dan luasnya cakupan pemeriksaan.

Penelitian ini berbeda dengan penelitian-penelitian sebelumnya, karena penelitian ini fokus pada upaya Perwakilan BPKP Aceh terhadap penerapan enam elemen kapabilitas APIP yang terdapat dalam IACM secara utuh terhadap 24 area proses kunci untuk menduduki posisi di level 3. Dengan demikian, penelitian ini diharapkan mampu berkontribusi praktik agar pemerintah daerah lainnya dapat mengadopsi upaya-upaya serta solusi yang dapat dilakukan sesuai enam elemen kapabilitas APIP. Berdasarkan uraian latar belakang tersebut, peneliti merasa tertarik untuk menganalisis apakah penerapan IACM terhadap APIP di wilayah Aceh berdampak positif sehingga mampu meningkatkan level kapabilitasnya dan apa saja upaya-upaya yang dilakukan untuk mencapainya.

\section{B. METODE PENELITIAN}

Pendekatan yang digunakan dalam penelitian ini adalah kualitatif dengan tipe studi kasus. Studi kasus bertujuan untuk melakukan penelaahan pada satu kasus atau lebih yang dilakukan secara intensif, mendalam, mendetail, dan komprehensif. Karakteristik studi kasus mempunyai sistematika dan kerangka yang lebih fleksibel, hal ini memungkinkan peneliti mengembangkan deskripsi dan analisis mendalam tentang bagaimana implementasi IACM yang diterapkan oleh Perwakilan BPKP Aceh dalam rangka meningkatkan level kapabilitas APIP. Pengumpulan data dilakukan dengan wawancara kepada Pejabat di Perwakilan BPKP Aceh. Penentuan narasumber tersebut dilakukan dengan metode purposive sampling karena peneliti menganggap narasumber yang dipilih benar-benar representatif sehingga dapat memberikan informasi yang akurat terhadap masalah yang diteliti. Selain wawancara, juga dilakukan studi pustaka dengan mengumpulkan data dan informasi pendukung lainnya, seperti Laporan Kinerja BPKP, Renstra dan sumber penunjang penulisan penelitian ini, seperti buku, jurnal, dan hasil penelitian. Lokus kajian ini adalah Perwakilan BPKP Aceh dengan fokus kajian pada penerapan IACM dalam meningkatkan kapabilitas APIP. Pelaksanaan penelitian ini dilakukan pada Januari sampai Februari 2020.

\section{KERANGKA TEORI}

Vander (2013) dalam Hidayah, K dkk, (2019:226) menyatakan bahwa sistem organisasi akan timpang apabila fungsi pengawasan dalam organisasi tersebut tidak berjalan sebagaimana mestinya. Senada dengan Yohanes (2018:57) bahwa fungsi pengawasan tidak mungkin berjalan sendiri tanpa fungsi perencanaan, demikian pula sebaliknya fungsi perencanaan yang baik adalah perencanaan yang didukung oleh pelaksanaan fungsi pengawasan yang baik. Putra (2017), menyimpulkan bahwa pengawasan intern dapat mendeteksi terjadinya fraud (kecurangan). Hal tersebut menurut Rustendi (2017:79) disebabkan oleh pengawasan intern yang dilakukan oleh auditor bisa dilakukan secara maksimal karena auditor internal terlibat melakukan pengawasan intern mulai dari tahapan perencanaan sampai pada pelaporan. Selain itu, auditor internal dianggap lebih memahami aktivitas organisasi sehingga auditor internal dapat mendeteksi secara lebih detail dan komprehensif terhadap aktivitas dan dokumen yang berpotensi menyebabkan fraud. Tohom (2016:7) juga menyebutkan bahwa proses identifikasi dan analisis risiko fraud dapat dibantu 
oleh APIP sebagai fasilititator. Kemudian APIP dapat membantu menyusun kebijakan dan prosedur pengendalian untuk meminimalkan risiko fraud tersebut.

Penelitian terkait pengawasan internal telah dilakukan oleh Widanarto (2012:12) yang meneliti tentang pengawasan internal, pengawasan eksternal, dan kinerja pemerintah. Hasilnya bahwa pengawasan internal yang cukup kuat berpengaruh langsung terhadap kinerja Pemerintah Kota Bandung. Tentu saja hal ini mengindikasikan cukup efektifnya pengawasan internal oleh inspektorat. Tidak hanya melihat dari pengawasan internal saja, penelitiannya juga menyoroti efektivitas kinerja pemerintah dari pengawasan eksternal. Disebutkan bahwa pengawasan eksternal dalam bentuk pengawasan legislatif dan masyarakat berpengaruh positif lemah secara individual. Hal ini disebabkan masih minimnya frekuensi peninjauan dan pengamatan langsung yang dilakukan, kurangnya pemanfaatan media informasi, dan masih lambannya upaya tindak lanjut dari pengawasan. Penelitian lain yang dilakukan oleh Gunanjar et al., (2019:27) dengan judul pengawasan dengan partisipasi masyarakat dan penerapannya di Indonesia menyebutkan bahwa masyarakat yang dapat dilibatkan dalam pengawasan dengan partisipasi masyarakat ada beberapa jenis, yaitu orang perseorangan, kelompok masyarakat, dan organisasi masyarakat. Namun, kurang profesionalnya partisipasi masyarakat di Indonesia, pengawasan masyarakat belum berperan kuat.

APIP merupakan aparat profesional yang memiliki sertifikat auditor dengan pemahaman mendalam tentang budaya bisnis organisasi, sistem dan proses audit (Kurniawan, 2018). Oleh karena itu, dalam melaksanakan tugas-tugas pengawasan, APIP diharapkan untuk mengikuti standar audit yang berlaku serta wajib mematuhi kode etik profesi. Dalam penelitian yang dilakukan oleh Budirahardjo \& Baskara (2019:144) disebutkan bahwa APIP belum menjalankan fungsinya secara efektif, dilihat dari sedikitnya temuan fraud bahwa 90\% dari penyalahgunaan anggaran di daerah adalah temuan BPK, KPK, Jaksa, dan Polisi, sementara 10\% sisanya adalah temuan Inspektorat. Mengingat hal tersebut, APIP perlu diperkuat kapabilitasnya agar dapat mendeteksi dan mengurangi terjadinya korupsi. Sehubungan dengan itu, untuk dapat memerankan auditor intern sebagai assurance maka metode audit yang dilakukan harus diperbaharui dari post audit (audit tahun lalu) menjadi current audit (audit tahun berjalan) (Sagara, 2015:130).

Apabila tingkat kapabilitas APIP berada di level 3, peran APIP yang efektif akan terwujud, karena APIP dianggap mampu menilai efisiensi dan efektivitas suatu program/kegiatan dan mampu memberikan konsultasi pada proses kegiatannya, manajemen risiko dan pengawasan intern. Oleh karena itu, setiap pemerintah daerah berusaha memperbaiki kapabilitas APIP ke level yang lebih tinggi. Bandi (2015:153) dalam penelitiannya juga menyatakan bahwa peningkatan kapabilitas APIP dari level 1 menjadi level 3 yang menjadi keinginan pemerintah menjadi keseriusan bagi APIP untuk meningkatkan kapabilitasnya dalam hal pengawasan secara optimal. Semakin tinggi tingkat kapabilitas APIP maka akan mampu mendukung pemerintah daerah dalam mewujudkan tata kelola keuangan negara/daerah yang akuntabel. Kurniawan (2018:11) mengemukakan bahwa level kapabilitas APIP berpengaruh positif terhadap akuntabilitas kinerja instansi pemerintah. Artinya, semakin tinggi kapabilitas APIP dalam melakukan audit kinerja, maka semakin akuntabel kinerja instansi pemerintah.

Ada lima level kapabilitas APIP, yaitu Level 1 (initial), Level 2 (infrastructure), Level 3 (integrated), Level 4 (managed) dan Level 5 (optimizing). Dalam Laporan Kinerja (BPKP, 2018:62) disebutkan bahwa: Level 1 (initial), memiliki karakteristik bahwa pelaksanaan kegiatan pengawasannya belum atau tidak ada praktik pengawasan yang tetap, tidak ada kapabilitas yang berulang dan masih tergantung kepada kinerja individu auditor yang 
dimiliki sehingga APIP belum dapat memberikan jaminan atas proses tata kelola sesuai peraturan dan mencegah korupsi. Level 2 (infrastructure), memiliki karakteristik bahwa pelaksanaan kegiatan pengawasannya proses audit dilakukan secara tetap, rutin dan berulang, sudah membangun infrastruktur namun baru sebagian yang telah selaras dengan standar audit, dengan outcome mampu memberikan keyakinan yang memadai proses sesuai dengan peraturan, mampu mendeteksi terjadinya korupsi.

Level 3 (integrated), memiliki karakteristik bahwa praktik profesional dan audit internal telah ditetapkan secara seragam dan selaras dengan standar, dengan outcome APIP mampu menilai efisiensi, efektivitas dan ekonomis suatu program/kegiatan dan memberikan konsultasi pada tata kelola, manajemen risiko dan pengedalian intern. Level 4 (managed), memiliki karakteristik bahwa unit audit internal telah mengintegrasikan semua informasi di seluruh organisasi untuk memperbaiki tata kelola dan manajemen risiko dengan outcome APIP mampu memberikan assurance secara keseluruhan atas tata kelola, manajemen risiko, dan pengendalian intern. Level 5 (optimizing), memiliki karakteristik bahwa unit audit internal telah menjadi unit yang terus belajar, baik dari dalam maupun dari luar organisasi untuk perbaikan berkelanjutan, dengan outcome APIP menjadi agen perubahan.

Tingkatan tersebut menggambarkan apabila tingkat kapabilitas APIP semakin mendekati level 5, kapabilitas APIP tersebut semakin baik. Berdasarkan Maryani (2017:90) bahwa IACM dapat dijadikan roadmap untuk pelaksanaan perbaikan secara bertahap dalam rangka memperkuat kemampuan internal audit. Tidak disebutkan upaya-upaya yang dapat dijadikan best practice dalam penerapan IACM. Penelitian tersebut menganalisis institusionaliasi IACM menggunakan teori institusional dan teori perubahan untuk melihat fenomena yang terjadi. Sehingga penelitiannya diharapkan dapat memberikan kontribusi teoritis yang menjelaskan bahwa teori institusional masih sangat relevan digunakan untuk menganalisis dan memahami pengadopsian suatu sistem yang dapat mendorong perubahan organisasi.

Setiap level kapabilitas memiliki beberapa area proses kunci (key process area). Area proses kunci adalah hasil yang diharapkan dan dipertahankan secara berkelanjutan agar dapat naik ke level berikutnya. Secara keseluruhan ada 41 area proses kunci untuk mencapai level 5. Untuk mencapai level kapabilitas yang diharapkan, organisasi APIP harus menguasai seluruh area proses kunci secara keseluruhan pada level tersebut. Area-area proses kunci tiap level dalam IACM dikategorikan dalam enam elemen kapabilitas APIP, yaitu (a) peran dan layanan APIP; (b) pengelolaan SDM; (c) praktik profesional; (d) akuntabilitas dan manajemen kinerja; (e) budaya dan hubungan organisasi; dan (f) struktur tata kelola APIP. Berikut matrik enam elemen kapabilitas APIP.

Tabel 3.

Level Kapabilitas APIP

\begin{tabular}{|c|c|c|c|c|c|c|}
\hline Level & $\begin{array}{l}\text { Peran dan } \\
\text { Layanan }\end{array}$ & $\begin{array}{l}\text { Pengelolaan } \\
\text { SDM }\end{array}$ & $\begin{array}{c}\text { Praktik } \\
\text { Profesional }\end{array}$ & $\begin{array}{c}\text { Akuntabilitas } \\
\text { dan Manajemen } \\
\text { Kinerja }\end{array}$ & $\begin{array}{c}\text { Budaya dan } \\
\text { Hubungan } \\
\text { Organisasi }\end{array}$ & $\begin{array}{l}\text { Struktur Tata } \\
\text { Kelola }\end{array}$ \\
\hline \multirow[t]{2}{*}{$\begin{array}{c}\text { Level 5- } \\
\text { Optimizing }\end{array}$} & $\begin{array}{c}\text { APIP diakui } \\
\text { sebagai agen } \\
\text { perubahan }\end{array}$ & $\begin{array}{c}\text { Pimpinan APIP } \\
\text { berperan aktif } \\
\text { dalam organisasi } \\
\text { profesi }\end{array}$ & $\begin{array}{c}\text { Praktik } \\
\text { professional } \\
\text { dikembangkan } \\
\text { secara } \\
\text { berkelanjutan }\end{array}$ & $\begin{array}{c}\text { Laporan } \\
\text { efektivitas APIP } \\
\text { kepada publik }\end{array}$ & $\begin{array}{l}\text { Hubungan } \\
\text { berjalan efektif } \\
\text { dan terus } \\
\text { menerus }\end{array}$ & $\begin{array}{l}\text { Independensi, } \\
\text { kemampuan dan } \\
\text { kewenangan } \\
\text { penuh APIP }\end{array}$ \\
\hline & & $\begin{array}{c}\text { Proyeksi } \\
\text { tenaga/tim kerja }\end{array}$ & $\begin{array}{l}\text { APIP memiliki } \\
\text { perencanaan } \\
\text { startegis }\end{array}$ & & & \\
\hline
\end{tabular}


Rati Sumant

\begin{tabular}{|c|c|c|c|c|c|c|}
\hline Level & $\begin{array}{l}\text { Peran dan } \\
\text { Layanan }\end{array}$ & $\begin{array}{l}\text { Pengelolaan } \\
\text { SDM }\end{array}$ & $\begin{array}{c}\text { Praktik } \\
\text { Profesional }\end{array}$ & $\begin{array}{c}\text { Akuntabilitas } \\
\text { dan Manajemen } \\
\text { Kinerja }\end{array}$ & $\begin{array}{l}\text { Budaya dan } \\
\text { Hubungan } \\
\text { Organisasi }\end{array}$ & $\begin{array}{l}\text { Struktur Tata } \\
\text { Kelola }\end{array}$ \\
\hline \multirow[t]{3}{*}{$\begin{array}{l}\text { Level 4- } \\
\text { Managed }\end{array}$} & \multirow[t]{3}{*}{$\begin{array}{c}\text { Jaminan } \\
\text { menyeluruh } \\
\text { atas tata kelola, } \\
\text { manajemen } \\
\text { risiko dan } \\
\text { pengendalian } \\
\text { organisasi }\end{array}$} & $\begin{array}{c}\text { APIP } \\
\text { berkontribusi } \\
\text { terhadap } \\
\text { pengembangan } \\
\text { manajemen }\end{array}$ & \multirow[t]{3}{*}{$\begin{array}{c}\text { Strategi audit } \\
\text { memanfaatkan } \\
\text { manajemen risiko } \\
\text { organisasi }\end{array}$} & \multirow[t]{3}{*}{$\begin{array}{c}\text { Penggabungan } \\
\text { ukuran kinerja } \\
\text { kualitatif dan } \\
\text { kuantitatif }\end{array}$} & \multirow[t]{3}{*}{$\begin{array}{l}\text { Pimpinan APIP } \\
\text { mampu } \\
\text { memberikan } \\
\text { saran dan } \\
\text { mempengaruhi } \\
\text { manajemen }\end{array}$} & $\begin{array}{l}\text { Pengawasan } \\
\text { independen } \\
\text { terhadap } \\
\text { kegiatan APIP }\end{array}$ \\
\hline & & $\begin{array}{l}\text { APIP } \\
\text { mendukung } \\
\text { organisasi } \\
\text { profesi }\end{array}$ & & & & $\begin{array}{c}\text { Laporan } \\
\text { pimpinan APIP } \\
\text { kepada } \\
\text { pimpinan } \\
\text { tertinggi }\end{array}$ \\
\hline & & $\begin{array}{l}\text { Perencanaan } \\
\text { tenaga/tim kerja }\end{array}$ & & & & organisasi \\
\hline \multirow[t]{3}{*}{$\begin{array}{l}\text { Level 3- } \\
\text { Integrated }\end{array}$} & \multirow[t]{2}{*}{$\begin{array}{l}\text { Layanan } \\
\text { konsultasi }\end{array}$} & $\begin{array}{l}\text { Membangun tim } \\
\text { dan kompetensi }\end{array}$ & $\begin{array}{l}\text { Kualitas kerangka } \\
\text { kerja manajemen }\end{array}$ & $\begin{array}{l}\text { Pengukuran } \\
\text { kinerja }\end{array}$ & \multirow{2}{*}{$\begin{array}{l}\text { Koordinasi } \\
\text { pihak lain } \\
\text { memberikan } \\
\text { saran dan } \\
\text { penjaminan }\end{array}$} & $\begin{array}{c}\text { Pengawasan } \\
\text { manajemen } \\
\text { terhadap }\end{array}$ \\
\hline & & $\begin{array}{l}\text { Pegawai yang } \\
\text { berkualifikasi }\end{array}$ & \multirow{2}{*}{$\begin{array}{l}\text { Perencanaan } \\
\text { audit berbasis } \\
\text { risiko }\end{array}$} & Informasi biaya & & kegiatan APIP \\
\hline & $\begin{array}{l}\text { Audit kinerja/ } \\
\text { program } \\
\text { evaluasi }\end{array}$ & Koordinasi Tim & & $\begin{array}{l}\text { Pelaporan } \\
\text { Manajemen } \\
\text { APIP }\end{array}$ & $\begin{array}{l}\text { Komponen } \\
\text { manajemen tim } \\
\text { integral }\end{array}$ & $\begin{array}{l}\text { Mekanisme } \\
\text { pendanaan }\end{array}$ \\
\hline \multirow[t]{2}{*}{$\begin{array}{c}\text { Level 2- } \\
\text { Infrastructure }\end{array}$} & \multirow[t]{2}{*}{ Audit ketaatan } & $\begin{array}{l}\text { Pengembangan } \\
\text { proses individu }\end{array}$ & $\begin{array}{l}\text { Kerangka kerja } \\
\text { praktik } \\
\text { profesional dan } \\
\text { prosesnya }\end{array}$ & $\begin{array}{c}\text { Anggaran } \\
\text { operasional } \\
\text { kegiatan APIP }\end{array}$ & \multirow[t]{2}{*}{$\begin{array}{l}\text { Pengelolaan } \\
\text { organisasi } \\
\text { APIP }\end{array}$} & $\begin{array}{c}\text { Akses penuh } \\
\text { terhadap } \\
\text { informasi } \\
\text { organisasi, aset } \\
\text { dan SDM }\end{array}$ \\
\hline & & $\begin{array}{l}\text { rekrutmen SDM } \\
\text { yang kompeten }\end{array}$ & $\begin{array}{l}\text { Pengawasan } \\
\text { berdasarkan } \\
\text { prioritas } \\
\text { pemangku } \\
\text { kepentingan }\end{array}$ & $\begin{array}{l}\text { Perencanaan } \\
\text { kegiatan APIP }\end{array}$ & & $\begin{array}{l}\text { Hubungan } \\
\text { pelaporan telah } \\
\text { terbangun }\end{array}$ \\
\hline $\begin{array}{l}\text { Level 1- } \\
\text { Initial }\end{array}$ & \multicolumn{6}{|c|}{$\begin{array}{l}\text { Ad hoc dan tidak terstruktur, audit terbatas untuk ketaatan, output tergantung pada keahlian orang pada posisi tertentu, } \\
\text { tidak menerapkan praktik professional secara spesifik selain yang ditetapkan asosiasi profesional, pendanaan } \\
\text { disetujui oleh manajemen sesuai yang diperlukan, tidak ada infrastruktur, auditor diperlakukan sama seperti sebagian } \\
\text { besar unit organisasi, tidak ada kapabilitas yang dibangun. Oleh karena itu tidak memiliki area proses kunci yang } \\
\text { spesifik. }\end{array}$} \\
\hline
\end{tabular}

Sumber: Peraturan Kepala BPKP Nomor: Per-1633/K/JF/2011 tentang Pedoman Teknis Peningkatan Kapabilitas Aparat Pengawasan Intern Pemerintah

\section{HASIL DAN PEMBAHASAN}

Berdasarkan temuan kajian diketahui bahwa Perwakilan BPKP Aceh telah mengimplementasikan IACM melalui enam elemen kapabilitas APIP, yaitu (a) peran dan layanan APIP; (b) pengelolaan SDM; (c) praktik profesional; (d) akuntabilitas dan manajemen kinerja; (e) budaya dan hubungan organisasi; dan (f) struktur tata kelola APIP. Elemen (a) sampai dengan (d) adalah area peningkatan dalam ruang lingkup internal, artinya pencapaiannya bergantung pada kemampuan APIP sendiri untuk mewujudkannya. Sedangkan elemen (e) dan (f) juga mencakup hubungan eksternal dengan organisasi yang didukungnya. Untuk mencapai level 2, APIP harus menguasai 10 area proses kunci dan untuk mencapai level 3 maka APIP harus menguasai 24 area proses kunci secara keseluruhan. Adapun upaya yang dilakukan pada enam elemen tersebut adalah sebagai berikut. 


\section{Elemen Peran dan layanan}

Untuk mencapai level 2, pada elemen ini, ada satu area proses kunci yang harus dilakukan, yaitu audit ketaatan. Outcome audit ketaatan ini terdiri dari tiga yaitu: (1) Mampu memberikan keyakinan bahwa lingkup, proses atau sistem operasional pengawasan intern telah dilaksanakan sesuai peraturan dan kriteria lain yang relevan. (2) Adanya added value untuk mencapai tujuan organisasi dan efektivitas operasional. (3) Minimnya kejadian dan terdeteksinya tindakan penyimpangan yang tidak sesuai. Upaya yang sudah dilakukan perwakilan BPKP Aceh adalah dengan pembinaan melalui kegiatan workshop audit Penghitungan Kerugian Keuangan Negara (PKKN) di Banda Aceh yang diikuti SDM dari inspektorat se-Aceh. Selanjutnya juga dilakukan kegiatan workshop audit investigasi dan audit PKKN yang dilakukan bersama dengan Komisi Pemberantasan Korupsi (KPK) di Banda Aceh yang diikuti oleh seluruh APIP di Aceh.

Sedangkan untuk memperoleh level 3, ada 2 area proses kunci yang harus dicapai, yaitu audit kinerja dan jasa konsultasi. Outcome dari audit kinerja terdiri dari 3 yaitu: (1) Peningkatan proses tata kelola, manajemen risiko, dan pengendalian pada audit, (2) Berkontribusi meningkatkan efisiensi, efektivitas, dan kinerja instansi pemerintah, (3) Berkurangnya tingkat risiko organisasi. Audit kinerja berbeda dengan audit ketaatan seperti yang diungkapkan oleh Mahmudi (2015:194) dalam Masdan, Ilat, \& Pontoh (2017:152) yaitu suatu proses yang sistematis untuk mendapatkan dan mengevaluasi bukti-bukti secara objektif atas kinerja suatu organisasi, program, fungsi, atau aktivitas/kegiatan. Audit kinerja memastikan bahwa stakeholders di sektor publik dapat memperoleh informasi yang objektif dan independen mengenai kinerja manajemen sektor publik. Untuk mencapai hal tersebut, upaya yang sudah dilakukan oleh Perwakilan BPKP Aceh adalah dengan melaksanakan workshop audit kinerja di Inspektorat Aceh yang diikuti personil dari inspektorat se-Provinsi Aceh. Selain melaksanakan workshop, Perwakilan BPKP Aceh juga telah melaksanakan diklat audit kinerja dan coaching clinic audit kinerja mandiri pada beberapa APIP di wilayah Aceh.

Upaya yang dilakukan oleh Perwakilan BPKP Aceh tersebut beririsan dengan penelitian Sagara (2015:130) yang mengemukakan bahwa peran consulting yang dilakukan oleh APIP harus menempatkan auditor pada satu objek pemeriksaan (person in charge) sebagai konsultan dengan tugas melakukan pendampingan terhadap program/kegiatan yang sedang berjalan pada suatu objek pemeriksaan (current audit). Jadi, peran auditor lebih terfokus pada pemberian arahan-arahan terkait topik pemeriksaan yang dilakukan, memberikan koreksi atas kekeliruan pencatatan dan memberi pembinaan pada semua unit yang menjadi bagian dari pemerintahan daerah (Gamar \& Djamhuri, 2015).

Selanjutnya, untuk area proses kunci jasa konsultasi maka upaya yang sudah dilakukan Perwakilan BPKP Aceh adalah pembinaan terkait penugasan jasa advis melalui pelaksanaan Bimbingan Teknis Peningkatan Kapabilitas APIP Menuju Level 3 pada seluruh APIP yang ada di wilayah Aceh. Upaya tersebut senada dengan yang dilakukan oleh Inspektorat Kabupaten Gorontalo dalam Masdan et al., (2017:153) yaitu dalam bentuk pemberian pelatihan, bimbingan, dan pemberian nasihat kepada auditan.

Dari pembinaan tersebut diharapkan mampu mendorong perubahan untuk meningkatkan kegiatan organisasi dan mampu memberikan nilai tambah terhadap tindakan manajemen organisasi. Kedua hal tersebut merupakan outcome jasa konsultasi yang diharapkan. Sejalan dengan outcome tersebut, menurut Masdan et al., (2017:153), layanan konsultasi bertujuan untuk menganalisis masalah yang dihadapi auditan, juga memberi pedoman dan nasihat kepada auditan yang mencakup fasilitasi, pelatihan, reviu 
pengembangan sistem, self assessment atas pengendalian dan kinerja, coaching dan pemberian nasihat untuk memberikan nilai tambah auditan.

Berdasarkan uraian di atas, kesimpulan yang dapat ditarik untuk upaya untuk merealisasikan elemen peran dan layanan adalah dengan melakukan pelatihan-pelatihan, dan bimbingan teknis terkait audit kinerja. Upaya ini dilakukan untuk menambah informasi dan pengetahuan seluruh APIP di Aceh agar lebih mengetahui mekanisme audit kinerja yang baik.

"Perwakilan BPKP Aceh saat ini sudah berperan dalam melakukan pelatihanpelatihan seperti kegiatan workshop. Selain itu, kami juga lebih banyak berperan sebagai coach apabila inspektorat di daerah mengalami masalah terkait audit kinerja. Kami juga sudah membuka coaching clinic audit kinerja mandiri pada beberapa APIP di wilayah Aceh." (Pejabat di Perwakilan BPKP Aceh, 30 Januari 2020)

"Selain itu, Perwakilan BPKP Aceh juga telah membentuk Klinik Akuntabilitas Gampong Aceh. Klinik tersebut merupakan salah satu inovasi kami dalam melakukan pengawasan dan pembinaan kepada gamponggampong atau desa di Aceh yang kini sudah mengelola dana desa. Harapannya pengawasan dan pembinaan kami dapat menjangkau seluruh gampong di Aceh serta dapat meningkatkan kapabilitas aparat desa/gampong”. (Pejabat di Perwakilan BPKP Aceh, 30 Januari 2020)

\section{Elemen Pengelolaan SDM}

Untuk mencapai level 2, maka pada elemen ini ada dua area proses kunci yang harus dipenuhi, yaitu APIP harus menemukan dan merekrut SDM yang berkompeten selain itu APIP juga harus mengembangkan profesi auditor. Agar dapat melaksanakan tugas pengawasan dengan baik, auditor diharapkan memiliki kompetensi yang bisa diperoleh dengan mengikuti diklat sertifikasi auditor. Untuk mencapai area proses kunci tersebut, Perwakilan BPKP Aceh telah melakukan pembinaan kepada seluruh APIP di wilayah Aceh untuk melakukan penghitungan beban kerja APIP. Kegiatan dilakukan melalui pelaksanaan Bimbingan Teknis Peningkatan Kapabilitas APIP Menuju Level 3 pada seluruh APIP yang ada di wilayah Aceh.

Area proses kunci pengembangan profesi bagi auditor, outcome yang diharapakan agar memberikan keyakinan bahwa seluruh pegawai teknis pengawasan telah memenuhi persyaratan minimal kegiatan pengembangan profesi sesuai ketentuan standar audit, sertifikasi profesi dan kebijakan organisasi dan adanya komitmen dari setiap pegawai untuk menerapkan "life-long learning”. Kedua outcome tersebut tercapai, Perwakilan BPKP Aceh telah melakukan pembinaan terkait penerapan standar kompetensi APIP dengan berpedoman kepada Peraturan Kepala BPKP Nomor PER/211/K/JF/2010 tentang Standar Kompetensi Auditor melalui pelaksanaan Bimbingan Teknis Peningkatan Kapabilitas APIP Menuju Level 3 pada seluruh APIP yang ada di wilayah Aceh. Selain itu, juga Perwakilan BPKP Aceh telah melaksanakan ujian sertifikasi auditor, Ujian Inpassing jenjang jabatan auditor, dan ujian penyetaraan ijazah bagi SDM Auditor yang ada pada seluruh APIP di wilayah Aceh. Upaya yang dilakukan tersebut senada dengan Masdan et al., (2017:154), bahwa Inspektorat Kabupaten Gorontalo telah memiliki program pengembangan sertifikasi auditor dan secara rutin setiap tahun mengikutsertakan aparatnya untuk mengikuti pelatihan 
sertifikasi auditor, baik itu diklat pembentukan anggota tim, diklat penjenjangan ketua tim dan pengendali teknis, maupun diklat teknis substansi.

Untuk mencapai level 3, pada elemen pengelolaan SDM terdapat 3 area proses kunci, yaitu adanya koordinasi SDM APIP (workforce coordination), tersedianya SDM APIP yang berkualifikasi profesional serta adanya kompetensi dan team building. Tiap area proses kunci tersebut memiliki outcome yang berbeda-beda. Area proses kunci adanya koordinasi SDM APIP (workforce coordination) maka outcomenya adalah SDM APIP mampu melaksanakan rencana pengawasan dan kegiatan pengawasan diterapkan secara berkelanjutan. Upaya yang sudah dilakukan untuk mencapai outcome tersebut adalah pembinaan terkait penghitungan beban kerja APIP melalui pelaksanaan Bimbingan Teknis Peningkatan Kapabilitas APIP Menuju Level 3 pada Seluruh APIP yang ada di Wilayah Aceh.

Untuk area proses kunci tersedianya SDM APIP yang berkualifikasi profesional, outcome yang diharapkan adalah (1) Sistem karir dilaksanakan secara merit system; (2) Pegawai dapat menyelaraskan tujuan pribadinya dengan kualifikasi profesional yang diperlukan di APIP; (3) APIP berkomitmen meningkatkan kompetensi melalui kegiatan pembimbingan, pendidikan dan pelatihan, serta peningkatan keahlian pegawai; (4) Auditor internal dianggap sebagai karir/jabatan yang menarik.

Untuk mencapai outcome tersebut, upaya yang dilakukan Perwakilan BPKP Aceh adalah (1) Pelaksanaan Diklat Teknis Substantif seperti Diklat Audit Kinerja, Diklat Penghitungan Kerugian Keuangan Negara (PKKN), dan Diklat Audit Investigasi bagi seluruh APIP yang ada di wilayah Aceh; (2) Pembinaan terkait penerapan Peraturan Pusat Pembinaan Jabatan Fungsional Auditor BPKP melalui pelaksanaan Bimbingan Teknis Peningkatan Kapabilitas APIP Menuju Level 3 pada seluruh APIP yang ada di wilayah Aceh; (3) Evaluasi terhadap penerapan Peraturan Pusat Pembinaan Jabatan Fungsional Auditor BPKP pada APIP di wilayah Aceh.

Untuk area proses kunci adanya kompetensi dan team building maka Perwakilan BPKP Aceh telah melakukan pembinaan terkait pemenuhan Jamlat Auditor melalui pelaksanaan Bimbingan Teknis Peningkatan Kapabilitas APIP Menuju Level 3 pada seluruh APIP di Aceh. Kegiatan tersebut dilakukan agar tercapainya outcome, yaitu (1) Kegiatan pengawasan mencakup ruang lingkup yang lebih luas; (2) Pegawai memiliki kesempatan mengembangkan kapasitasnya di bidang komunikasi, leadership dan public relation. (3) Peningkatan kualitas pekerjaan dengan berbagi pengetahuan, pengalaman, dan sudut pandang yang berbeda dari beberapa pegawai.

Berdasarkan uraian capaian pada elemen pengelolaan SDM yang telah dilakukan oleh Perwakilan BPKP Aceh, dapat disimpulkan bahwa peningkatan kompetensi merupakan hal yang mutlak dilakukan agar tercapai SDM APIP yang berkualitas.

"Hasil kinerja seorang auditor bergantung pada tingkat kompetensinya, karena ketika seorang auditor mendeteksi sebuah kesalahan, seorang auditor harus didukung dengan pengetahuan tentang apa dan bagaimana kesalahan tersebut terjadi. Sehingga semakin tinggi kompetensi auditor akan semakin baik kualitas hasil pemerikasaannya." (Pejabat di Perwakilan BPKP Aceh, 30 Januari 2020).

Berdasarkan hasil penelitian Toding (2016:17) yang dilakukan di Kabupaten Sidoarjo bahwa APIP dalam melaksanakan tugas dan fungsi pengawasan secara umum dan fungsi pengawasan secara khusus, belum memenuhi standar kompetensi padahal kalau ditinjau dari segi latar belakang pendidikan formal dan disiplin ilmu sangat mendukung. Kondisi tersebut 
merupakan akibat dari (1) Struktur organisasi dan pola hubungan kerja belum sepenuhnya sesuai dengan strategi dalam mencapai tujuan APIP yang efektif; (2) Kurangnya kegiatan pengembangan kompetensi dan lemahnya manajemen SDM APIP terutama dalam hal rekrutmen dan pola karir; (3) Lemahnya manajemen/tata laksana/bisnis proses APIP dan tidak terpenuhinya kebutuhan formasi Auditor; (4) Independensi dan objektivitas APIP belum dapat diterapkan sepenuhnya.

Tidak hanya kompetensi, perspektif kuantitas sumber daya aparatur juga sangat diperlukan. Seperti hasil penelitian Yohanes (2018:61), bahwa keterbatasan sumber daya aparatur merupakan faktor utama yang menyebabkan tidak efektifnya penerapan konsep pemeriksaan dalam pelaksanaan pemeriksaan regular Inspektorat Kabupaten Bulungan. Diketahui bahwa dari 37 PNS di Inspektorat Kabupaten Bulungan hanya delapan orang aparatur yang memenuhi standar dalam arti telah memiliki sertifikat untuk melaksanakan penugasan audit intern. Akibatnya terjadi ketidakseimbangan antara jumlah aparatur dengan beban kerjanya. Selanjutnya, menurut hasil penelitian Marlaini, Aliamin, \& Indriani $\underline{(2018: 106)}$ yang menjadi penyebab belum diimplementasikannnya secara maksimal penguatan peran APIP pada inspektorat adalah formasi auditor dan calon auditor belum sebanding dengan kualitas yang diharapkan, kompetensi SDM auditor belum semuanya memadai, alokasi anggaran inspektorat yang masih kecil, lemahnya independensi inspektorat serta kurangnya objektivitas dari beberapa auditor.

Sebaliknya, yang menjadi faktor pengungkit baiknya kualitas audit yang dilakukan oleh APIP adalah reward. Hasil kajian yang dilakukan oleh Heriansyah, Taufik, \& Ratnawati (2016:12) mengungkapkan bahwa ternyata faktor reward mempengaruhi hubungan kompetensi dengan kualitas audit. Disebutkan dalam kajian tersebut bahwa reward dapat dijadikan salah satu alat untuk meningkatkan motivasi APIP agar dapat berkinerja lebih baik lagi. Senada dengan temuan di bagian pendahuluan bahwa APIP merupakan pihak yang dicari-cari pelaku korupsi untuk menutupi kecurangannya, terutama bila auditor diprediksi mampu mengetahui korupsi yang dilakukan. Tentunya hal tersebut dapat diminimalisir apabila reward yang baik diberikan kepada APIP.

\section{Elemen Praktik Profesional}

Untuk mencapai level 2, pada elemen praktik profesional ada dua area proses kunci yang harus diperhatikan bahwa perencanaan pengawasan dilakukan sesuai prioritas manajemen/pemangku kepentingan serta adanya kerangka kerja praktik profesional berikut prosesnya. Area proses kunci pertama memiliki outcome pemahaman APIP terkait prioritas Menteri/Kepala LPNK/Gubernur/Bupati/Wali Kota dan pihak lainnya juga dapat diprediksi peluang pengembangan untuk meningkatkan kinerja instansi. Untuk mencapai kedua outcome tersebut, Perwakilan BPKP Aceh melakukan pembinaan terkait penyusunan perencanaan pengawasan berdasarkan kebutuhan stakeholder melalui pelaksanaan Bimbingan Teknis Peningkatan Kapablitas APIP Menuju Level 3 seluruh APIP di Aceh.

Area proses kunci kedua juga memiliki dua outcome yang harus dicapai, yaitu penugasan pengawasan dilaksanakan dengan "due professional care" dan konsistensi dalam proses pengawasan internal dan kesesuaian dengan standar dan praktik profesional. Upaya yang sudah dilakukan Perwakilan BPKP Aceh untuk mencapai outcome tersebut adalah dengan melakukan pembinaan terkait penegakan independensi auditor serta kepatuhan terhadap kode etik seperti yang tertuang di dalam Internal Audit Charter (IAC) tiap-tiap APIP melalui pelaksanaan Bimbingan Teknis Peningkatan Kapabilitas APIP Menuju Level 3 pada seluruh APIP yang ada di wilayah Aceh. Selain itu, juga dilakukan pembinaan terkait 
penerapan kendali mutu penugasan APIP melalui pelaksanaan Bimbingan Teknis Peningkatan Kapabilitas APIP Menuju Level 3 pada seluruh APIP yang ada di wilayah Aceh.

Adapun jika ingin mencapai level 3, pada elemen ini terdapat dua area proses kunci meliputi adanya perencanaan pengawasan berbasis risiko dan kualitas kerangka kerja manajemen. Outcome yang diharapkan dari adanya perencanaan pengawasan berbasis risiko adalah terciptanya pemahaman terkait peluang dan tantangan organisasi serta peran serta manajemen dalam menghadapinya, sehingga meningkatkan manajemen risiko dan sistem pengendalian. Upaya yang mampu dilakukan Perwakilan BPKP Aceh adalah dengan melaksanakan kegiatan Diklat Penyusunan PKPT Berbasis Risiko untuk seluruh APIP di Wilayah Aceh.

Sedangkan outcome area proses kunci kualitas kerangka kerja manajemen, yaitu keyakinan yang memadai bahwa proses dan kegiatan APIP berkesesuaian dengan definisi internal auditing, kode etik, standar, dan ketentuan lain yang relevan dan meningkatnya kepercayaan stakeholders dengan adanya dokumentasi atas komitmen APIP terhadap kualitas penyelenggaraan pengawasan intern. Upaya pembinaan yang dilakukan oleh Perwakilan BPKP Aceh untuk mencapai outcome tersebut baru sebatas pelaksanaan kegiatan telaah sejawat antar APIP yang diikuti oleh seluruh APIP yang ada di wilayah Aceh. Kesimpulan yang dapat ditarik dari upaya yang sudah dilakukan oleh Perwakilan BPKP Aceh untuk mencapai elemen praktik profesional adalah perlunya penegakan kode etik auditor. Sesuai dengan kode etik yang tertuang dalam $I A C$, dalam menjalankan tugasnya seorang auditor harus selalu mempertahankan sikap independensi.

"Independensi bertujuan agar seorang auditor dapat memposisikan dirinya tidak memihak kepada orang-orang yang berkepentingan terhadap hasil auditnya. Ketika auditor tidak memiliki independensi, maka auditor akan sangat mudah dipengaruhi oleh pihak-pihak tertentu sehingga dapat mempengaruhi hasil audit yang tidak sesuai dengan keadaan sebenarnya." (Pejabat di Perwakilan BPKP Aceh, 30 Januari 2020)

Penelitian ini sejalan dengan penelitian terdahulu seperti yang dilakukan Apsari \& Gayatri (2018: 301) bahwa adanya pengaruh positif independensi pada kinerja auditor. Tidak hanya independensi, penelitian tersebut juga menemukan bahwa gaya kepemimpinan juga menjadi faktor yang menentukan kualitas audit. Oleh karena itu, seorang pimpinan harus mampu mempengaruhi kinerja bawahannya agar lebih produktif sehingga berpengaruh positif terhadap kinerja auditor.

Namun, hasil penelitian ini berbeda dengan hasil penelitian Urrahmi (2015: 10) yang menemukan bahwa independensi mempengaruhi kualitas audit aparat inspektorat dalam melakukan pengawasan. Namun demikian, hasil penelitian tersebut menyimpulkan bahwa adanya independensi yang tinggi dimiliki oleh auditor, maka akan semakin rendah pula kualitas audit yang dihasilkan. Diduga karena independensi aparat inspektorat kota di Sumatera Barat tersebut masih terpengaruh pengambil kebijakan dan tingginya frekuensi mutasi auditor internal pemerintahan yang mempengaruhi independensi auditor. Demikian juga dengan hasil penelitian Primasatya et al., (2019:7) yang menyebutkan bahwa independensi tidak berpengaruh terhadap efektivitas audit internal dikarenakan masih adanya kegiatan dari para auditor internal yang melemahkan keindependensian para auditor, seperti melakukan tugas lain selain audit dan masih belum bisa memberi nilai tambah bagi organisasi dalam mencapai tujuannya. 


\section{Elemen Akuntabilitas dan Manajemen Kinerja}

Untuk mencapai level 2, pada elemen ini terdapat dua area proses kunci yang perlu diperhatikan, yaitu adanya perencanaan kegiatan pengawasan serta adanya anggaran operasional kegiatan pengawasan. Pada area proses kunci adanya perencanaan kegiatan pengawasan memiliki outcome adanya rencana kinerja tahunan (RKT) yang dapat digunakan sebagai dasar untuk mengendalikan kegiatan pengawasan dan menjadi panduan bagi pimpinan APIP dalam mengakuntabilitaskan penggunaan sumber daya untuk mencapai tujuan pengawasan. Pembinaan yang telah dilakukan Perwakilan BPKP Aceh untuk mencapai outcome tersebut adalah dengan melakukan pembinaan terkait penyusunan Rencana Kinerja Tahunan (RKT) APIP melalui pelaksanaan Bimbingan Teknis Peningkatan Kapabilitas APIP Menuju Level 3 pada seluruh APIP yang ada di Aceh.

Pada area proses kunci, dengan adanya anggaran operasional kegiatan pengawasan, outcome yang diharapkan dapat tercapai, meliputi (1) APIP mengalokasikan sumber daya berdasarkan kebutuhan dan rencana pengawasan; (2) Penguatan akuntabilitas dalam organisasi; (3) Jaminan bahwa kegiatan pengawasan telah sesuai dengan kewenangan dan aset APIP telah terjaga dengan baik. Untuk mencapai ketiga outcome tersebut, Perwakilan BPKP Aceh telah melakukan pembinaan dengan melaksanaan kegiatan diklat Aplikasi Sistem Informasi Manajemen-Hasil Pengawasan (SIM-HP) BPKP bagi seluruh APIP di wilayah Aceh. Selain itu, Perwakilan BPKP Aceh telah melakukan evaluasi tindak lanjut temuan secara berkala pada seluruh APIP yang ada di wilayah Aceh.

Untuk mencapai level 3, pada elemen ini ada tiga area proses kunci yang harus dipenuhi, yaitu adanya laporan manajemen kegiatan pengawasan, adanya informasi mengenai biaya dan adanya sistem pengukuran kinerja. Untuk area proses kunci adanya manajemen kegiatan pengawasan, outcome yang diharapkan adalah ketepatan pelaksanaan tanggung jawab dan akuntabilitas manajemen APIP. Pembinaan yang dilakukan Perwakilan BPKP Aceh untuk mencapai outcome tersebut adalah pembinaan terkait penyusunan LAKIP APIP kepada Pimpinan Daerah melalui pelaksanaan Bimbingan Teknis Peningkatan Kapabilitas APIP Menuju Level 3 pada APIP yang ada di Aceh.

Pada area proses kunci adanya informasi mengenai biaya, outcome yang diharapkan bahwa informasi biaya dapat digunakan untuk mengendalikan biaya kegiatan/program pengawasan dan dimanfaatkan untuk mendukung pengambilan keputusan. Untuk mencapai outcome tersebut, upaya yang dilakukan oleh Perwakilan BPKP Aceh adalah pembinaan terkait penyusunan anggaran, revisi anggaran, serta penerapan standar biaya melalui pelaksanaan Bimbingan Teknis Peningkatan Kapabilitas APIP Menuju Level 3 pada seluruh APIP yang ada di Wilayah Aceh.

Pada area proses kunci adanya sistem pengukuran kinerja, maka outcome yang diharapkan adalah pemahaman dan pelaksanaan kegiatan pengawasan yang telah mengarah kepada pencapaian tujuan APIP dan tujuan organisasi dan manajemen APIP yang mampu memanfaatkan informasi kinerja untuk memonitor kegiatan dan hasil pengawasan. Untuk mencapai outcome tersebut, upaya yang sudah dilakukan oleh Perwakilan BPKP Aceh adalah pembinaan terkait penetapan Indikator Kinerja Utama (IKU) APIP melalui pelaksanaan Bimbingan Teknis Peningkatan Kapablitas APIP Menuju Level 3 pada seluruh APIP yang ada di wilayah Aceh. Selain itu, Perwakilan BPKP Aceh juga melakukan pembinaan terkait penyusunan LAKIP APIP kepada Pimpinan Daerah melalui pelaksanaan Bimbingan Teknis Peningkatan Kapabilitas APIP Menuju Level 3 pada Seluruh APIP yang ada di Wilayah Aceh. 
"Elemen akuntabilitas dan manajemen kinerja dapat tercapai apabila indikator-indikatornya dapat dilaksanakan seperti adanya Rencana Kinerja Tahunan (RKT), terlaksananya Indikator Kinerja Utama (IKU) yang sudah ditetapkan serta laporan kinerja yang temuat dalam LAKIP. Oleh sebab itu, kami berupaya melakukan pembinaan terkait penyusunan ketiga dokumen tersebut kepada seluruh inspektorat yang ada di Aceh." (Pejabat di Perwakilan BPKP Aceh, 30 Januari 2020)

Beririsan dengan penelitian yang dilakukan oleh Rahman \& Zulkarnaini (2017:13) bahwa semakin memadainya penerapan pengawasan akuntabilitas maka akan semakin efektif kinerja manajemen pada Rumah Sakit Umum Sakinah Kota Lhokseumawe, sehingga menunjukkan tercapainya kinerja manajemen yang bersih, adil, transparan, dan akuntabel. Auditya \& Lismawati (2013:38) dalam penelitiannya yang berjudul "analisis pengaruh akuntabilitas dan transparansi pengelolaan keuangan daerah terhadap kinerja pemerintah daerah" juga menyimpulkan bahwa berdasarkan hasil pengujian hipotesisnya, variabel akuntabilitas berpengaruh positif dan signifikan terhadap kinerja SKPD Provinsi Bengkulu. Itu artinya semakin akuntabel pengelolaan keuangan dan pelaporan keuangan dalam SKPD Pemerintah Provinsi Bengkulu, maka akan semakin meningkatkan kinerja. Akuntabilitas tinggi pada pengelolaan keuangan diharapkan bisa meningkatkan kepercayaan masyarakat terhadap pemerintah sehingga dapat menciptakan iklim investasi yang baik.

\section{Elemen Budaya dan Hubungan Organisasi}

Untuk mencapai level 2, pada elemen budaya dan hubungan organisasi terdapat satu area proses kunci yang harus dicapai yaitu adanya pengelolaan atas proses bisnis pengawasan intern. Agar area proses kunci tersebut terealisasi, outcome yang harus dipenuhi adalah APIP mampu berfungsi memberikan nilai tambah kepada organisasi. Upaya yang dilakukan Perwakilan BPKP Aceh agar APIP di seluruh wilayah Aceh mampu mencapai outcome tersebut adalah dengan pembinaan terkait uraian jabatan dan Standar Organisasi dan Tata Kelola (SOTK) APIP melalui pelaksanaan Bimbingan Teknis Peningkatan Kapabilitas APIP Menuju Level 3 pada seluruh APIP ada di wilayah Aceh.

Untuk mencapai level 3, ada dua area proses kunci yang harus dipenuhi, yaitu APIP bersama-sama dengan unit lain dalam organisasi merupakan satu tim manajemen dan koordinasi dengan stakeholder yang memberikan saran dan penjaminan. Pada area proses kunci pertama, outcome-nya adalah bahwa pimpinan APIP merupakan unsur yang memiliki peran penting dalam tim manajemen organisasi dan berkontribusi dalam pencapaian tujuan organisasi. Untuk mencapai outcome tersebut, pembinaan yang sudah dilakukan oleh Perwakilan BPKP Aceh adalah pembinaan terkait keterlibatan peran APIP dalam manajemen pimpinan daerah melalui pelaksanaan Bimbingan Teknis Peningkatan Kapabilitas APIP Menuju Level 3 pada seluruh APIP yang ada di wilayah Aceh.

Pada area proses kunci kedua, outcome yang harus dipenuhi adalah pengoptimalan hubungan dan meminimalkan tumpang tindih kegiatan APIP dengan unit pemberi penjaminan dan saran lainnya dan meningkatan level penjaminan karena adanya kolaborasi kegiatan antara APIP dengan fungsi risk dan control dalam organisasi (first dan second lines of defense).

"Untuk merealisasikan outcome tersebut maka pembinaan yang sudah dilakukan oleh Perwakilan BPKP Aceh adalah pembinaan terkait hubungan koordinasi APIP dengan lembaga penjamin mutu eksternal melalui 
pelaksanaan Bimbingan Teknis Peningkatan Kapabilitas APIP Menuju Level 3 pada seluruh APIP yang ada di wilayah Aceh. Selain itu juga, Perwakilan BPKP Aceh juga telah melaksanakan workshop identifikasi dan analisis risiko yang diikuti oleh seluruh APIP di wilayah Aceh." (Pejabat di Perwakilan BPKP Aceh, 30 Januari 2020)

\section{Elemen Struktur Tata Kelola}

Untuk mencapai level 2, pada elemen ini ada dua area proses kunci, yaitu adanya mekanisme pendanaan kegiatan pengawasan dan adanya pengawasan terhadap pelaksanaan kegiatan APIP oleh manajemen organisasi Pemerintah Daerah. Pada area proses kunci pertama, outcome yang harus dicapai adalah penguatan independensi, objektivitas, dan efektivitas APIP. Selain itu, nilai tambah yang diciptakan APIP tercermin dari dukungan Kepala Daerah sehingga Kepala Daerah ikut bertanggung jawab terhadap efektivitas APIP. Upaya yang sudah dilakukan oleh Perwakilan BPKP Aceh adalah pembinaan terkait pembentukan Management Oversight (MO) pada manajemen Pemerintah Daerah melalui pelaksanaan Bimbingan Teknis Peningkatan Kapabilitas APIP Menuju Level 3 pada seluruh APIP yang ada di wilayah Aceh.

Untuk area proses kunci kedua, outcome yang harus dicapai adalah (1) Permasalahan hubungan kelembagaan sudah dimitigasi/ditangani oleh Kepala Daerah; (2) Berkurangnya tumpang tindih pengawasan; (3) Peran dan tanggung jawab dari three lines of defense (manajemen operasional; manajemen Risiko dan unit kepatuhan internal; serta APIP) telah dipahami, dikoordinasikan dan berjalan secara efektif. Upaya yang sudah dilakukan oleh Perwakilan BPKP Aceh agar outcome tersebut tercapai adalah dengan melakukan pembinaan terkait pembentukan Management Oversight (MO) pada manajemen Pemerintah Daerah melalui pelaksanaan Bimbingan teknis Peningkatan Kapabilitas APIP Menuju Level 3 pada Seluruh APIP yang ada di wilayah Aceh. Dari deskripsi di atas dapat disimpulkan bahwa untuk mencapai elemen struktur tata kelola, diperlukan adanya management oversight di setiap pemerintah daerah. Pemerintah daerah agar membentuk tim pengawasan yang bertugas mengawasi, mengevaluasi, dan memberi dukungan kegiatan APIP. Management oversight harus dilaksanakan untuk mencapai penyelenggaraan birokrasi yang bersih dan bebas dari korupsi.

"Perwakilan BPKP Aceh telah melakukan pembinaan kepada seluruh inspektorat di Aceh terkait pembentukan management oversight yaitu tim pengawasan APIP. Nantinya pembentukan tim ini akan dilakukan oleh Gubernur/Bupati/Walikota sebagai pimpinan tertinggi di daerah." (Pejabat di Perwakilan BPKP Aceh, 30 Januari 2020)

Berdasarkan pembahasan enam elemen di atas, bahwa peran pembinaan yang dilakukan oleh Perwakilan BPKP Aceh berpengaruh positif terhadap peningkatan kapabilitas APIP. Terbukti 16 APIP Pemerintah Daerah atau 67\% dari jumlah APIP di wilayah Aceh yang mengalami peningkatan level kapabilitas. Sedangkan delapan APIP Pemerintah Daerah atau 33\% dari jumlah APIP di wilayah Aceh belum meningkat. Hasil penjaminan kapabilitas APIP terlihat dari tabel 4.

Berdasarkan tabel di atas diketahui bahwa penerapan Internal Audit Capability Model (IACM) untuk meningkatkan kapabilitas APIP di Aceh sangat efektif, meskipun masih ada beberapa elemen yang masih memerlukan perbaikan. Adapun elemen tersebut adalah peran dan layanan, pengelolaan SDM dan praktik profesional. Adapun pada elemen peran dan 
layanan, masih memerlukan perbaikan karena audit ketaatan dan audit kinerja yang dilaksanakan belum sepenuhnya didasarkan pada kegiatan yang berisiko tinggi dan kemampuan SDM APIP dalam melaksanakan audit kinerja masih minim.

Tabel 4.

Hasil Penjaminan Kapabilitas APIP di Wilayah Aceh

\begin{tabular}{llccc}
\hline No & \multicolumn{1}{c}{ Nama Pemda } & 2018 & 2019 & Status \\
\hline 1 & Pemerintah Aceh & 2 & $2+$ & Meningkat \\
2 & Kota Banda Aceh & $2+$ & 3 & Meningkat \\
3 & Kota Langsa & $2+$ & 3 & Meningkat \\
4 & Kabupaten Aceh Barat & $2+$ & 3 & Meningkat \\
5 & Kota Lhokseumawe & 2 & 3 & Meningkat \\
6 & Kabupaten Aceh Utara & $2+$ & 3 & Meningkat \\
7 & Kabupaten Aceh Selatan & $2+$ & 3 & Meningkat \\
8 & Kabupaten Bener Meriah & $2+$ & 3 & Meningkat \\
9 & Kabupaten Pidie & 2 & 3 & Meningkat \\
10 & Kabupaten Gayo Lues & 2 & $2+$ & Meningkat \\
11 & Kabupaten Aceh Singkil & 2 & $2+$ & Meningkat \\
12 & Kabupaten Pidie Jaya & 2 & $2+$ & Meningkat \\
13 & Kota Subulussalam & 2 & $2+$ & Meningkat \\
14 & Kabupaten Aceh Tamiang & 2 & $2+$ & Meningkat \\
15 & Kabupaten Aceh Jaya & 1 & 2 & Meningkat \\
16 & Kabupaten Bireun & $1+$ & 2 & Meningkat \\
17 & Kabupaten Aceh Timur & $2+$ & $2+$ & Tetap \\
18 & Kabupaten Aceh Tengah & $2+$ & $2+$ & Tetap \\
19 & Kabupaten Simeulue & 2 & 2 & Tetap \\
20 & Kabupaten Aceh Barat Daya & 2 & 2 & Tetap \\
21 & Kabupaten Aceh Besar & 2 & 2 & Tetap \\
22 & Kabupaten Nagan Raya & 2 & 2 & Tetap \\
23 & Kabupaten Aceh Tenggara & 2 & 2 & Tetap \\
24 & Kota Sabang & $1+$ & $1+$ & Tetap \\
\hline
\end{tabular}

Sumber: Perwakilan BPKP Aceh

"Pada elemen pengelolaan SDM, masih memerlukan perbaikan karena masih kurangnya jumlah SDM APIP apalagi yang berkualifikasi profesional melalui keikutsertaan pada diklat teknis substantif dan mempunyai sertifikasi profesi dalam rangka mendukung pelaksanaan tugas pengawasan. Selain itu APIP juga belum didukung dengan anggaran yang memadai untuk meningkatkan kompetensi auditor di bidang teknis substantif dan sertifikasi profesi." (Pejabat di Perwakilan BPKP Aceh, 30 Januari 2020)

Pernyataan narasumber tersebut senada dengan temuan Budirahardjo \& Baskara, (2019: 147), bahwa APIP perlu diperkuat dalam hal institusi, anggaran, dan kapabilitasnya. Hal ini agar APIP dapat berperan efektif dan efisien dalam melakukan pengawasan intern pemerintah. Di sisi lain, Masdan et al., (2017:157), menyatakan upaya yang dapat dilakukan untuk meningkatkan kompetensi dengan menambah wawasan sendiri, baik dengan cara rajin membaca maupun berdiskusi mengenai aturan terbaru serta melakukan Pelatihan Kantor Sendiri (PKS). Pegawai yang pernah mengikuti pelatihan dapat membagi ilmu yang 
diperoleh selama mengikuti pelatihan kepada teman-teman di kantor yang tidak mengikuti pelatihan.

Pada elemen praktik profesional, masih diperlukan perbaikan karena penilaian risiko yang dilakukan belum memadai sehingga kegiatan audit yang terpilih pada penyusunan perencanaan berbasis risiko (PPBR) belum mampu mengurangi paparan risiko strategis organisasi. Juga belum kesinambungannya pengelolaan kualitas pengawasan intern melalui review berjenjang sebagai penerapan kendali mutu. Hasil penelitian Fahmi \& Sari (2018:13) juga menemukan bahwa elemen praktik profesional adalah elemen yang belum tercapai secara maksimal dikarenakan Inspektorat Kota Tebing Tinggi belum mampu mengidentifikasi alternatif penanganan risiko yang dilakukan oleh manajemen, juga belum menerapkan upaya menjaga kualitas kegiatan pengawasan sesuai dengan pedoman telaah sejawat dalam rangka penjaminan kegiatan pengawasan yang telah dilaksanakan.

\section{E. PENUTUP}

Semakin tinggi level kapabilitas APIP menunjukkan kualitas APIP yang semakin baik dalam menjalankan perannya sebagai auditor intern. Oleh karenanya Perwakilan BPKP Aceh sebagai instansi Pembina APIP di wilayah Aceh berusaha maksimal mewujudkan hal tersebut dengan menerapkan $I A C M$ secara menyeluruh. Ada enam elemen yang saling terintegrasi dapat meningkatkan kapabilitas APIP. Untuk elemen pertama yaitu peran dan layanan APIP telah dilakukan pelatihan dan bimbingan teknis terkait audit kinerja juga pembentukan coaching clinic dan klinik akuntabilitas gampong Aceh. Terkait elemen kedua, yaitu pengelolaan SDM, dilakukan pelatihan untuk meningkatkan kompetensi auditor. Untuk elemen ketiga praktik profesional, telah dilakukan pembinaan terkait penegakan kode etik auditor. Sedangkan untuk elemen keempat, yaitu akuntabilitas dan manajemen kinerja, dilakukan pembinaan terkait penyusunan Rencana Kinerja Tahunan, Indikator Kinerja Utama dan Penyusunan dokumen LAKIP. Adapun pada elemen kelima, yaitu budaya dan hubungan organisasi dilakukan pembinaan terkait hubungan koordinasi APIP dengan lembaga penjamin mutu eksternal. Sedangkan untuk elemen terakhir struktur tata kelola APIP, upaya yang dilakukan adalah pembinaan kepada seluruh inspektorat di Aceh terkait pembentukan management oversight, yaitu tim pengawasan APIP.

Berdasarkan penjelasan tersebut dapat disimpulkan bahwa penerapan model IACM yang dilakukan oleh Perwakilan BPKP Aceh menunjukkan dampak positif bagi peningkatan kapabilitas APIP di Aceh. Terbukti dari 24 APIP di wilayah Aceh, 16 APIP Pemerintah Daerah atau $67 \%$ yang mengalami peningkatan level kapabilitas. Hasil penelitian ini telah menguatkan penelitian sebelumnya yang dilakukan oleh Maryani (2017:101) bahwa institusionalisasi IACM di Kementerian Luar Negeri berimplikasi terhadap APIP yang semakin mampu mengenal kondisi kemampuan yang dimiliki, kapabilitas internal auditornya dan perbaikan yang perlu dilakukan untuk pengembangannya baik individu, tim dan organisasi. Namun disisi lain, penelitian ini juga memperluas kajian sebelumnya tidak hanya berkontribusi secara teoritis tetapi penelitian ini juga berkontribusi secara praktis bahwa upaya-upaya yang dilakukan oleh Perwakilan BPKP Aceh dalam rangka meningkatkan kapabilitas APIP di daerah dapat dijadikan best practice bagi daerah lainnya. Selanjutnya, dari penelitian ini juga ditawarkan model sinergi yang dapat mendukung percepatan terjadinya peningkatan kapabilitas APIP di Aceh. Adapun model sinergi yang dapat diterapkan adalah "trilateral synergy". Model ini menggambarkan sinergi peran antara tiga pihak yang berkepentingan dalam peningkatan kapabilitas APIP di Aceh. Tiga pihak yang dimaksud adalah Perwakilan BPKP Aceh selaku instansi Pembina APIP, Kepala Daerah selaku Pimpinan Tertinggi di daerah dan APIP itu sendiri. Adapun peran masing- 
masing pihak antara lain, Perwakilan BPKP Aceh terus berupaya melakukan pembinaan terhadap APIP agar seluruh APIP di wilayah Aceh mampu meningkatkan lagi level kapabilitasnya. Sedangkan kepala daerah berperan penting mengawal setiap pelaksanaan tugas dan fungsi APIP di daerahnya serta memberikan tekanan (pressure) bagi APIP masih berada di level rendah untuk terus memperbaiki kinerja sehingga mencapai kapabilitas pada level berikutnya. Selain itu, kepala daerah juga perlu menerapkan reward and punishment kepada APIP sehingga hal tersebut dapat menjadi stimulant agar APIP lebih termotivasi dalam meningkatkan kapabilitasnya. Adapun APIP sendiri berperan semaksimal mungkin untuk melakukan upaya terbaik dalam melakukan pengawasan internal sehingga mampu memberikan jaminan tata kelola pemerintahan yang baik dalam pencegahan korupsi. Sinergi yang baik antara tiga pihak tersebut diharapkan dapat mempercepat peningkatan kapabilitas APIP di Aceh.

\section{DAFTAR PUSTAKA}

Apsari, N. N. S., \& Gayatri. (2018). Pengaruh Independensi, Gaya Kepemimpinan, Komitmen Organisasi, Pengalaman Kerja, dan Pemahaman Good Governance pada Kinerja Auditor. E-Jurnal Akuntansi Universitas Udayana, 24(1), 282-310. https://doi.org/https://doi.org/10.24843/EJA.2018.v24.i01.p11

Auditya, L., \& Lismawati, H. (2013). Analisis Pengaruh Akuntabilitas dan Transparansi Pengelolaan Keuangan Daerah Terhadap Kinerja Pemerintah Daerah. Jurnal Fairness, 3(1), 21-41.

Bandi, I. W. (2015). Pengaruh E-Government, Kapabilitas APIP dan Persentasi Penyelesaian Tindak Lanjut Terhadap Opini Audit Laporan Keuangan Pemerintah Daerah Di Indonesia. Jurnal Akuntansi Dan Bisnis, 15(2), 148-157.

BPKP. (2018). Laporan Kinerja BPKP 2018. Jakarta : BPKP

BPKP. (2018). Siaran Pers Konferensi dan Musyawarah Nasional Auditor Intern Pemerintah Indonesia Tahun 2018. Retrieved from http://pusbinjfa.bpkp.go.id/berita/208-Konferensi-dan-Musyawarah-Nasional-

Auditor-Intern-Pemerintah-Indonesia-Tahun-2-18.

Budirahardjo, R., \& Baskara, S. A. B. (2019). Revitalizing and Strengthening The Role of APIP In Building Strong Tone At The Top As An Effort To Prevent Corruption In Indonesia. Asia Pacific Fraud Journal, 4(2), 139-149. Retrieved from http://www.apfjournal.or.id/index.php/apf

Darmawiguna, I. M. Y. (2017). Pengaruh Peran Aparat Pengawas Intern Pemerintah Terhadap Penerapan Good Governance dan Implikasinya Pada Kinerja Pemerintah. EJurnal Akuntansi Universitas Udayana, 18(3), 2172-2201.

Fahmi, M., \& Sari, D. R. (2018). Analisis Kapabilitas Aparat Pengawasan Internal Pemerintah (APIP) Menggunakan Standart Internal Audit Capability Model (IACM). Jurnal Bina Akuntansi, 29(1), 1-16.

Gamar, N., \& Djamhuri, A. (2015). Auditor Internal Sebagai “Dokter" Fraud Di Pemerintah Daerah. Jurnal Akuntansi Multiparadigma, 6(1), 107-123. https://doi.org/10.18202/jamal.2015.04.6009

Gunanjar, G. G., Nurhayati, S., Mujiyanto, \& Rachman, Y. P. (2019). Pengawasan Dengan Partisipasi Masyarakat dan Penerapannya Di Indonesia. Jurnal Pengawasan, 1(1), 18 28.

Heriansyah, M. I., Taufik, T., \& Ratnawati, V. (2016). Pengaruh Reward sebagai Variabel Moderasi dengan Kompetensi, Independensi, Pengalaman Kerja dan Keahlian Profesional terhadap Kualitas Audit. Sorot, 11(1), 1-14. 
https://doi.org/10.31258/sorot.11.1.3884

Hidayah, K., Wismono, F. H., Kusumaningrum, M., \& Amarullah, R. (2019). Peran Inspektorat Daerah Kota Samarinda dalam Mempertahankan Opini Wajar Tanpa Pengecualian (WTP). Jurnal Borneo Administrator, 15(2), 221-236. https://doi.org/10.24258/jba.v15i2.538

Kurniawan, A. R. (2018). Pengaruh Karakteristik Aparat Pengawasan Intern Pemerintah (APIP) Terhadap Akuntabilitas Kinerja Instansi Pemerintah. Jurnal Akuntansi, 6(1), 1$\underline{20 .}$

Marlaini, Aliamin, \& Indriani, M. (2018). Evaluasi Efektivitas Penguatan Peran Aparat Pengawasan Intern Pemerintah Dalam Paradigma Baru (Studi Kasus Pada Salah Satu Inspektorat Di Aceh). Jurnal Perspektif Ekonomi Darussalam, 4(1), 95-108. https://doi.org/10.24815/jped.v4i1.10926

Maryani, T. (2017). Institusionalisasi Internal Audit Capability Model Pada Aparat Pengawasan Intern Pemerintah (Studi Kasus di Kementerian Luar Negeri). Ekonomi Bisnis, 22(2), 87-102.

Masdan, S. R., Ilat, V., \& Pontoh, W. (2017). Analisis Kendala-Kendala Peningkatan Kapabilitas Aparat Pengawasan Intern Pemerintah (APIP) pada Inspektorat Kabupaten Gorontalo. Jurnal Riset Akuntansi Dan Auditing "Goodwill," 8(2), 150-159. https://doi.org/10.35800/jjs.v8i2.17780

Perwakilan BPKP Aceh. (2019). Laporan Kinerja Perwakilan BPKP Aceh Tahun 2019. Retrieved from http://www.bpkp.go.id/aceh/konten/3156/Laporan-KinerjaPerwakilan-BPKP-Aceh-Triwulan-I-2019.bpkp.

Primasatya, R. D., Puspitasari, M. D., Hasundungan, R., \& Laila, E. A. (2019). Faktor-Faktor Yang Memengaruhi Efektivitas Audit Internal Inspektorat se-Karesidenan B. Jurnal Pengawasan, 1(1), 1-9.

Puslatbang, KHAN. (2019). Implementasi Undang-Undang Nomor 30 Tahun 2014 tentang Administrasi Pemerintahan Terkait Pemberantasan Korupsi (1st ed.; S. Fadhil, Ed.). Retrieved from http://aceh.lan.go.id/download/5723/

Putra, T. A. P. S. (2017). Pengaruh Independensi, Kompetensi, dan Pengalaman Auditor Aparat Pengawas Intern Pemerintah (APIP) Terhadap Pendeteksian Fraud Dengan Skeptisisme Profesional Sebagai Variabel Intervening Pada Perwakilan BPKP Provinsi Kepulauan Riau. Coopetition, 8(1), 67-83.

Rahman, B., \& Zulkarnaini. (2017). Pengaruh Pengawasan Akuntabilitas Terhadap Kinerja Manajemen Pada Rumah Sakit Umum Sakinah Kota Lhokseumawe. Jurnal Akuntansi Pembangunan, 3(1), 1-14.

Rustendi, T. (2017). Peran Audit Internal Dalam Memerangi Korupsi (Upaya Meningkatkan Efektivitas Fungsi APIP). Jurnal Akuntansi, 12(2), 111-126. Retrieved from http://jurnal.unsil.ac.id/index.php/jak/article/view/384/280

Sagara, Y. (2015). Efektivitas Peran Auditor Internal Di UIN Syarif Hidayatullah Jakarta yang Ditunjukkan oleh PP No.60 Tahun 2008: Sistem Pengendalian Intern Pemerintah (SPIP). Jurnal Bisnis Dan Manajemen, 5(1), 119-132.

Toding, D. S. (2016). Kapasitas Aparat Inspektorat dalam Pengawasan Keuangan Daerah Kabupaten Sidoarjo (Kajian terhadap Kompetensi Aparat Inspektorat di Kabupaten Sidoarjo). Jurnal Ilmiah Administrasi Publik, 2(1), 11-18.

Tohom, A. (2016). Peran Pengawasan Internal dalam Menghindari Kutukan Sumber Daya Alam. Liquidity, 5(1), 1-9.

Urrahmi, M. (2015). Pengaruh Independensi, Kompetensi, Motivasi, Objektivitas, Integritas, Pengalaman Kerja dan Etika terhadap Kualitas Audit Aparat Inspektorat dalam 
Pengawasan Keuangan Daerah ( Studi Empiris pada Inspektorat Pemerintah Kota di Sumatera Barat). Jurnal Online Mahasiswa Fakultas Ekonomi Universitas Riau, 2(2), $1-14$.

Widanarto, A. (2012). Pengawasan Internal, Pengawasan Eksternal dan Kinerja Pemerintah. Jurnal Ilmu Administrasi Negara, 12(1), 1-18.

Yohanes, E. (2018). Peran Aparat Pengawas Intern Pemerintah (APIP) dalam Penyelenggaraan Pemerintahan Daerah Di Kabupaten Bulungan. Jurnal Paradigma, 7(2), 65-78. 
